\title{
一腹きょうだい数が子豚の発育，育成豚の産肉， 繁殖能力に及ぼす影響
}

\author{
鈴木啓一・西田 茂・氏家 哲・福田智子・佐藤秀俊 \\ 宮城県畜産試験場，宮城県玉造郡岩出山町，989-64 \\ （1990 年 6 月 1 日 受付）
}

\begin{abstract}
要 約一腹きょうだい数の大きさが子豚の発育や系統造成試験での検定成績, 繁殖豚の能力に影響 を及ぼすかどうか検討した。系統造成の選抜第 1 から第 6 世代までのランドレース種の子豚 2216 頭の 8 週齢までの体重と増体量, 育成雄豚 291 頭と育成雌豚 735 頭の産肉成績および繁殖豚 239 頭の繁殖成 績を分析に用いた。子豚は 2 週齢で餌付けを開始し， 5 週齢で離乳した。離乳頭数を一腹きょうだい数 とし，7頭未満，8～9 頭，10 11 頭，12 頭以上の 4 つに区分した。出生時と $1 ， 2 ， 3 ， 4 ， 5$ および 8 週歯体重と出生から 2 週齢, 2 週齢から 5 週㱓までの増体量について, きょうだい数 7 頭未満と 12 頭 以上の間にそれぞれ $0.1 \mathrm{~kg} ， 0.31 \mathrm{~kg} ， 0.58 \mathrm{~kg}, 1.08 \mathrm{~kg}, 1.62 \mathrm{~kg} ， 2.04 \mathrm{~kg}$ ，および $2.64 \mathrm{~kg}$ と $0.47 \mathrm{~kg}$ および $1.47 \mathrm{~kg}$ の有意な差が認められ，一腹きょうだい数が多いと発育が劣ることが示された。 しかし，5から8 週齢までの増体量に関しては効果は有意でなかった。育成雄, 育成雌豚の 8 週齢体重 と $30 \mathrm{~kg}$ 日齢に対し, 一腹きょうだい数の効果は有意だが, $90 \mathrm{~kg}$ 到達日齢, 1 日平均増体量, 背脂肪 厚, 1 平均飼料摂取量, 飼料要求率および選抜指数値, さらに, 雌豚の分娩頭数, 生産頭数に対しては 一腹きょうだい数は影響しないことが明らかとなった。これらの結果は, 一腹きょうだい数の豚の発育, 産肉形質に及ぼす影響は日齢が進むに従い減少することを示唆している。
\end{abstract}

\section{緒言}

豚の発育に及ぼす母性効果や一腹きょうだい数の影響 については多くの研究がなされ，一腹きょうだい数の多 い腹で育成された豚は少ない腹で育成された豚より子豚 の時期の発育が遅く, 種雌豚としての繁殖能力む低いこ とが報告されている ${ }^{1 \sim 4)}$ 。国内の試験研究機関で実施さ れている豚の系統造成試験では, 多くの場合, 分婏時一 腹の哺乳子豚数を揃えず育成している。そし，一腹きょ うだい数の大小が育成豚の発育, 産肉能力および種雌豚 の繁殖能力によ゙の程度の影響を及ぼしているか明らかで ない。むし, 影響が大きいとすると遺伝的な能力の正確 な把握ができず，選抜の正確度が低下するため記録の補 正が必要となる。そこで, 本報告では系統造成試験で得

Effects of fraternity size on the growth of piglets, and meat production and reproduction traits of growing pigs.

K. Suzuki and S. Nishida. S. UjiIe, T. FuKUDA and H. SATO

Miyagi Prefectural Animal Industry Experiment Station, Iwadeyama-cho, Miyagi, 989-64
られた成績を用い，一腹きょうだい数が子豚の発育と育 成豚の産肉, 繁殖能力にどの程度の影響を及ぼしている か検討した。

\section{材料と方法}

子豚の発育に及ぼす一腹きょうだい数の影響を見るた め, 宮城県で実施中の系統造成の第 1 世代から第 6 世代 のランドレース種の子豚 2216 頭の 8 週齢までの発育記 録を用いた。子豚は分婏後 2 週齢加ら餌付けを開始し, 5 週齢で離乳した。体重の測定は 5 週齢までの各週と 8 週㱓で行った。なお，里子を出したり，里親となった腹 の記録は全て除いた。出生時と 1 から 5 週齢までの各週 齢と 8 週齢時の体重，出生時汃ら 2 週齢， 2 週齢加ら 5 週㱓さらに 5 週齢から 8 週齢までの各期間の増体量につ いて世代，一腹きょうだい数および性を母数，種雄豚を 変量要因とした最小二乗法による分散分析を行った。週 齢間の増体をこのように決めたのは，2 週齢および 5 週 齢が䭒付け開始および離乳時点となっているためである。 なお，一腹きょうだい数は離乳時点の 5 週齢での生存頭 数とし, 7 頭未満, 8 から 9 頭, 10 から 11 頭, 12 頭以 
表 1. 子豚の発育に及ぼす世代，性と一腹きょうだい数の影響

Table 1. The effects of generation, sex and fraternity size on the growth of piglets.

\begin{tabular}{cccccccccccc}
\hline \hline & & \multicolumn{1}{c}{ Mean squres for } \\
Source & d.f & W0 & W1 & W2 & W3 & W4 & W5 & W8 & G02 & G25 & G58 \\
\hline Generation (G) & 5 & $0.714^{*}$ & 1.756 & 4.92 & 9.48 & 13.9 & $40.7^{* *}$ & $167.3^{* *}$ & 3.66 & $20.7^{* *}$ & $99.26^{* *}$ \\
$\quad$ Sire (S) & 50 & $0.274^{* *}$ & $1.138^{* *}$ & $2.57^{* *}$ & $5.01^{* *}$ & $7.1^{* *}$ & $10.1^{* *}$ & $48.0^{* *}$ & $1.83^{* *}$ & $4.3^{* *}$ & $22.60^{* *}$ \\
Fraternity size(L) & 3 & $1.264^{* *}$ & $7.192^{* *}$ & $24.65^{* *}$ & $72.62^{* *}$ & $160.8^{* *}$ & $265.1^{* *}$ & $465.5^{* *}$ & $14.90^{* *}$ & $128.2^{* *}$ & 31.67 \\
G $\times$ L & 15 & 0.346 & 1.360 & 2.56 & 3.96 & 5.5 & 6.0 & 25.7 & 1.48 & 2.2 & 13.86 \\
S $\times$ L & 78 & $0.205^{*}$ & $1.081^{* *}$ & $2.64^{* *}$ & $4.76^{* *}$ & $6.6^{* *}$ & $8.8^{* *}$ & $36.9^{* *}$ & $1.81^{* *}$ & $3.7^{* *}$ & $17.62^{* *}$ \\
Sex & 1 & $1.140^{* *}$ & $1.085^{* *}$ & $1.69^{*}$ & $4.32^{*}$ & $5.4^{*}$ & 2.2 & 0.2 & 0.05 & 0.0 & 2.58 \\
Remainder & 2063 & 0.047 & 0.153 & 0.40 & 0.74 & 1.1 & 1.6 & 6.5 & 0.27 & 0.7 & 3.14 \\
\hline
\end{tabular}

W0, W1, W2, W3, W4, W5, W8 : Body weight at $0,1,2,3,4,5,8$ weeks of age.

G02, G25, G58 : Body weight gain at each period from 0 to 2 , from 2 to 5 and from 5 to 8 weeks of age.

${ }^{*} \mathrm{P}<0.05,{ }^{* *} \mathrm{P}<0.01$.

\section{上の 4 区分とした。}

育成豚の産肉能力に及ぼす一腹きょうだい数の影響の 検討は，選拔第 1 世代加ら第 6 世代までの育成雄 291 頭, 育成雌豚 735 頭の検定成績について行った。さらに繁殖 成績に及ぼす影響については, 育成雌豚のうち選抜され, 分婏した 239 頭の繁殖成績を用いて検討した。なお，こ れら育成豚および繁殖豚の成績には里子あ含めた。検定 成績は $30 \mathrm{~kg}$ 到達日齢, $90 \mathrm{~kg}$ 到達日齢, 1 日平均増体 量, 背脂肪厚, ロース断面積および選抜指数值（育成雄, 育成雌), 1 日平均飼料摂取量, 飼料要求率 (育成雄) であり, 繁殖成績は分娩頭数と生産頭数とした。各形質 について世代と一腹きょうだい数を母数, 種雄豚を変量 要因とした最小二乗法による分散分析を行った。

分析は全て HARVEY のプログラム LSMLMW ${ }^{5)}$ 使用して行った。

\section{結果}

子豚の体重と増体量について世代，一腹きょうだい数， 性および種雄豚を要因とした分散分析の結果を表 1 に示 した。世代の効果は出生時体重, 5 と 8 週噛体重, 2 か ら 5 週齢と 5 から 8 週齢までの増体量について認められ た。世代の経過に伴い, 第 4 世代まで体重, 増体量とあ 増加傾向にあったが，第 5,6 世代と減少した。また， 一腹きょうだい数の効果については全ての週齢の体重で 有意であった。増体については出生から 2 週龄, 2 週齢 から 5 週齢までの期間では有意であったが， 5 週齢から 8 週秢の期間の増体では有意な効果は認められなかった。 さらに，性の効果は出生時と $1,2,3,4$ 週齢体重では 有意だが， 5 週齢と 8 週齢体重および各期間の増体は有
表 2. 子豚の体重と増体量の一腹きょうだい数別最小 二乗平均値

Table 2. Least square means for body weight and body weight gain of piglets of each fraternity size.

\begin{tabular}{llrrrr}
\hline \hline \multirow{2}{*}{ Trait } & \multicolumn{5}{c}{ Fraternity size } \\
& & -7 & $8-9$ & $10-11$ & $12-$ \\
\hline \multirow{3}{*}{ Body } & W0 & 1.35 & 1.31 & 1.22 & 1.24 \\
weight & W1 & 2.59 & 2.46 & 2.29 & 2.28 \\
(kg) & W3 & 4.30 & 4.14 & 3.79 & 3.72 \\
& W4 & 8.00 & 5.83 & 5.33 & 5.00 \\
& W5 & 10.02 & 9.37 & 8.37 & 7.98 \\
Body weight & G02 & 2.94 & 2.83 & 2.57 & 2.47 \\
gain & G25 & 5.72 & 5.21 & 4.57 & 4.25 \\
(kg) & G58 & 8.92 & 9.08 & 8.65 & 8.38 \\
\hline
\end{tabular}

意ではなかった。出生から 4 週歯までの体重は雄が雌よ り有意に重いが， 5 週齢以後は差が認められなかった。 各週齢間の増体の性間差が認められなかったことから 4 週齢までの体重差は出生時の体重差が反映されたものと 思われる。表 2 に子豚の発育について一腹きょうだい数 別の最小二乗平均値を示した。出生時から $1,2,3,4$, 5 および 8 週榆時の体重について， 7 頭未満と 12 頭以上 との間でそれぞれ $0.11 \mathrm{~kg}, 0.31 \mathrm{~kg}, 0.58 \mathrm{~kg}, 1.08 \mathrm{~kg}$, $1.62 \mathrm{~kg}, 2.04 \mathrm{~kg}, 2.64 \mathrm{~kg}$ の差が認められた。また, 増体量では出生から 2 週，2 から 5 週齢間でそれぞれ $0.47 \mathrm{~kg}$ と $1.47 \mathrm{~kg}$ の有意な差が認められたが, 5 から 8 週齿間の増体については各きょうだい区分間の差 
表 3. 育成雄豚の発育に及ぼす世代と一腹きょうだい数の影響

Table 3. The effects of generation and fraternity size on the growing performance of boars.

\begin{tabular}{lcccccccccc}
\hline Source & d.f. & \multicolumn{1}{c}{ Mean squres for } & & & \\
& & 8WBW & $30 \mathrm{~kg}$ Age & $90 \mathrm{kgAge}$ & DG & BF & EM & SI & DFI & FCR \\
\hline Generation & 5 & $309^{* *}$ & $68^{* *}$ & $742^{* *}$ & $57296^{* *}$ & $66^{* *}$ & $8009^{*}$ & $248611^{* *}$ & $143^{*}$ & $622^{* *}$ \\
$\quad$ Sire & 51 & 66 & 16 & 60 & 2852 & $7^{* *}$ & $1134^{* *}$ & 7208 & 42 & $37^{*}$ \\
Fraternity size & 3 & $238^{* *}$ & $88^{*}$ & 54 & 1992 & 3 & 15 & 8182 & 47 & 7 \\
$\quad$ Remainder & 231 & 60 & 20 & 50 & 2289 & 4 & 653 & 5638 & 39 & 25 \\
\hline
\end{tabular}

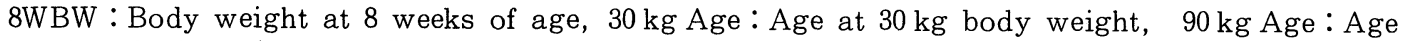
at $90 \mathrm{~kg}$ body weight, DG:Daily gain, BF : Backfat thickness, EM: Eye muscle area, SI: Selection index, DFI: Daily feed intake, FCR: Feed conversion ratio.

$* \mathrm{P}<0.05, \quad * * \mathrm{P}<0.01$

（0.54kg）は統計的に有意ではなかった。このように， 一腹きょうだい数の影響は哺乳期間に大きく，離乳後は その効果が徐々に減少することが明らかとなった。

育成雄の産肉形質について分散分析の結果を表 3 に示 した。世代の効果は全ての形質について認められた。各 形質とも第 4 世代まで好ましい方向に改良されたが，第 5 世代以降は横ばい傾向であった。また，一腹きょうだ い数の効果は 8 週齢体重と $30 \mathrm{~kg}$ 到達日齢で有意だっ たが，その他の形質についてはいずれも有意でなかった。 一腹きょうだい数別の最小二乗平均值を表 4 に示した。 8 週齢体重では一腹きょうだい数 7 頭末満が $20.1 \mathrm{~kg}$, 12 頭以上が $18.6 \mathrm{~kg}$ と $1.5 \mathrm{~kg}$ の差が認められた。さ らに， $30 \mathrm{~kg}$ 到達日齢についてあ 8〜9 頭と 12 頭以上で それぞれ 72.8 日と 76 日で約 3 日の有意な差が認められ たが他の形質については有意な差が認められなかった。

育成雌の産肉形質について分散分析を行った結果を表 5 に示したが，育成雄と同様な結果が得られた。即ち， 世代の効果については全ての形質について認められ，90 $\mathrm{kg}$ 到達日齢, 1 日平均増体量および選抜指数值につい ては第 6 世代まで一貫して改良されたが，背脂肪厚につ いては第 4 世代まで，ロース断面積については第 5 世代
表 4. 育成雄豚の産肉形質の一腹きょうだい数別最小 二乗平均值

Table 4. Least square means for performance traits of boars of each fraternity size.

\begin{tabular}{|c|c|c|c|c|c|}
\hline \multirow[t]{2}{*}{ Traits } & & \multicolumn{4}{|c|}{ Fraternity size } \\
\hline & & -7 & $8-9$ & $10-11$ & $12-$ \\
\hline 8WBW & $\mathrm{kg}$ & 20.1 & 20.3 & 19.5 & 18.6 \\
\hline $30 \mathrm{~kg} \mathrm{Age}$ & day & 74.1 & 72.8 & 73.3 & 76.0 \\
\hline $90 \mathrm{~kg} \mathrm{Age}$ & day & 154.1 & 153.6 & 153.2 & 155.7 \\
\hline DG & $\mathrm{g}$ & 779.5 & 778.9 & 791.1 & 789.1 \\
\hline $\mathrm{BF}$ & $\mathrm{cm}$ & 1.76 & 1.79 & 1.74 & 1.77 \\
\hline EM & $\mathrm{cm}^{2}$ & 33.07 & 33.14 & 33.14 & 33.22 \\
\hline SI & & 59.82 & 58.81 & 61.61 & 60.43 \\
\hline DFI & $\mathrm{kg}$ & 2.27 & 2.28 & 2.30 & 2.28 \\
\hline FCR & & 2.923 & 2.937 & 2.912 & 2.915 \\
\hline
\end{tabular}

まで改良され，その後は横ばい傾向であった。一腹きょ うだい数の効果については 8 週齢体重と $30 \mathrm{~kg}$ 到達日 齢は有意だが，その他の形質については有意な効果は認 められなかった。一腹きょうだい数別に最小二乗平均值 をみると（表 6)，まず， 8 週龄体重は 7 頭末満と 12 頭 以上でそれぞれ $19.6 \mathrm{~kg}$ と $17.8 \mathrm{~kg}$ で $1.8 \mathrm{~kg}$ の有意な

表 5. 育成雌豚の成長に及ぼす世代と一腹きょうだい数の影響

Table 5. The effects of generation and fraternity size on the growing performance of gilts

\begin{tabular}{lrcccccccc}
\hline \hline \multirow{2}{*}{ Source } & d.f. & \multicolumn{9}{c}{ Mean squres for } \\
& & 8WBW & 30kg Age & 90kg Age & DG & BF & EM & SI \\
\hline Generation & 5 & $700^{* *}$ & $547^{* *}$ & $9718^{* *}$ & $475484^{* *}$ & $223^{* *}$ & $5269^{*}$ & $1126422^{* *}$ \\
Sire & 50 & $183^{* *}$ & $81^{* *}$ & $344^{* *}$ & $10929^{* *}$ & $13^{* *}$ & $1828^{* *}$ & $29954^{* *}$ \\
Fraternity size & 3 & $912^{* *}$ & $274^{* *}$ & 259 & 7627 & 7 & 1423 & 8851 \\
$\quad$ Remainder & 676 & 54 & 28 & 110 & 3902 & 5 & 734 & 7218 \\
\hline
\end{tabular}

8 WBW : Body weight at 8 weeks of age, $30 \mathrm{~kg}$ Age: Age at $30 \mathrm{~kg}$ body weight. $90 \mathrm{~kg}$ Age : Age at $90 \mathrm{~kg}$ body weight, DG:Daily gain, BF : Backfat thickness, EM: Eye muscle area, SI: Selection index.

$* \mathrm{P}<0.05, \quad * * \mathrm{P}<0.01$ 
表 6. 育成雌豚の産肉形質の一腹きょうだい数別最小 二乗平均値

Table 6. Least square means for performance traits of gilts of each fraterniy size.

\begin{tabular}{|c|c|c|c|c|c|}
\hline \multirow{2}{*}{\multicolumn{2}{|c|}{ Traits }} & \multicolumn{4}{|c|}{ Fraternity size } \\
\hline & & -7 & $8-9$ & $10-11$ & $12-$ \\
\hline 8WBW & & 19.6 & 19.1 & 17.8 & 17.8 \\
\hline $30 \mathrm{~kg} \mathrm{Age}$ & day & 74.2 & 75.0 & 76.9 & 77.7 \\
\hline $90 \mathrm{~kg} \mathrm{Age}$ & day & 163.9 & 163.2 & 164.2 & 166.7 \\
\hline DG & $\mathrm{g}$ & 707.7 & 715.3 & 723.2 & 707.1 \\
\hline $\mathrm{BF}$ & $\mathrm{cm}$ & 1.99 & 1.99 & 1.98 & 1.93 \\
\hline EM & $\mathrm{cm}^{2}$ & 33.99 & 33.31 & 33.78 & 33.99 \\
\hline SI & & 64.13 & 64.08 & 65.61 & 65.42 \\
\hline
\end{tabular}

表 7. 繁殖雌豚の繁殖能力に及ぼす世代と一腹きょうだ い数の影響

Table 7. The effects of generation and fraternity size on the reproduction traits of gilts.

\begin{tabular}{|c|c|c|c|}
\hline Source & d.f. & $\begin{array}{l}\text { Mear } \\
\text { Litter } \\
\text { born }\end{array}$ & $\begin{array}{l}\text { Litter size } \\
\text { born live }\end{array}$ \\
\hline Generation & 4 & 7.69 & 21.5 \\
\hline Sire & 43 & 9.77 & 8.7 \\
\hline Fraternity size & 3 & 5.71 & 4.2 \\
\hline Remainder & 188 & 7.16 & 7.0 \\
\hline
\end{tabular}

表 8. 繁殖成績の一腹きょうだい数別最小二乗平均値 Table 8. Least square means for reproduction traits of each fraternity size

\begin{tabular}{lcrcc}
\hline \hline Traits & \multicolumn{4}{c}{ Fraternity size } \\
& -7 & \multicolumn{1}{c}{$8-9$} & $10-11$ & $12-$ \\
\hline Litter size born & 9.98 & 10.58 & 11.07 & 10.97 \\
Litter size born live & 9.45 & 9.65 & 10.06 & 10.33 \\
\hline
\end{tabular}

差が認められた。つぎに, $30 \mathrm{~kg}$ 到達日齢について一腹 きょうだい数が 7 頭未満のものは 12 頭以上より $30 \mathrm{~kg}$ 検定開始日齢が約 3 日有意に短かった。しかし, 育成雌 豚の $90 \mathrm{~kg}$ 到達日齢, 1 日平均增体量, 背脂肪厚, 口ス断面積, 選抜指数值については一腹きょうだい数別に みるといずれの形質とも有意な差か認められなかった。

育成雌豚の繁殖成績について分散分析の結果を表 7 に 示した。いずれの効果とも有意でなかった。表 8 には， 一腹きょうだい数別に分婏頭数，生産頭数を示した。一 腹きょうだい数 12 頭以上の分婏頭数, 生産頭数が 10.97 ,
10. 33 頭と 7 頭未満の 9.98，9.45 頭より多い傾向だが 有意ではなかった。

\section{考察}

豚の発育性, 肥育性の諸形質值の変動要因としては遺 伝のほか, 性, 母性効果, そのうちであ母の産次, 一腹 子豚数, 暦年の影響が大きいとされる ${ }^{6)}$ 。本研究では哺 乳期間の一腹きょうだい数が, 子豚の発育之育成豚の産 肉能力, 繁殖能力に及ぼす影響を検討した。その結果, まず一腹きょうだい数の大小は子豚の初期 (ほ乳期) の 発育には大きな影響を及ぼすが，5週龄の離乳時以降 8 週齢時までの増体を見るとその影響が徐々に薄れること が明らかとなった。また，一腹きょうだい数は育成豚の 8 週齢時体重や $30 \mathrm{~kg}$ 到達日齢などの発育には影響す るが, $90 \mathrm{~kg}$ 日齢や 1 日平均増体量, 背脂肪厚, ロース 断面積および選抜指数值などの形質には影響しないこと が明らかとなった。子豚全頭の比較では 7 頭未満と 12 頭以上の間の 8 週齢体重の差は $2.64 \mathrm{~kg}$ であったが, 育成雄, 雌ではその差は $1.5 \mathrm{~kg}$ と $1.8 \mathrm{~kg}$ とかなり小 さかった。これは，8週粈の第 1 次選抜で育成候補豚を 選抜する場合, 相対的に体重の大きいあのが選ばれ小さ い子豚は淘汰されたためと思われる。このように, 比較 的体重の大きい子豚が第 1 次選抜で育成豚として選ばれ た結果と離乳後次第に発現してきた代償成長により, 哺 乳時期の一腹きょうだい数の大小は育成豚の産肉能力に はほとんど影響しなかったものと思われる。

一腹きょうだい数の子豚の発育と育成豚の産肉能力に 及ぼす影響に関して, NELSON and ROBISON ${ }^{1)}$ は里子 交換により産子を 6 頭と 14 頭に揃えて，子豚の発育と 背脂肪厚を調查した。その結果, 6 頭区と 14 頭の両区 間の $2,4,6$ および 8 週齢体重はそれぞれ $4.06 \mathrm{~kg}$ と $3.57 \mathrm{~kg}, 7.36 \mathrm{~kg}$ と $5.94 \mathrm{~kg}, 10.96 \mathrm{~kg}$ と $8.19 \mathrm{~kg}$, $16.51 \mathrm{~kg}$ と $12.02 \mathrm{~kg}$ であり両区間の差は $0.49 \mathrm{~kg}$, $1.42 \mathrm{~kg} ， 2.77 \mathrm{~kg}$ および $4.49 \mathrm{~kg}$ と週齢が増すにつれ て增加した。しかし，20 週歯体重は $70.9 \mathrm{~kg}$ と $65.5 \mathrm{~kg}$ でありその差は $5.4 \mathrm{~kg}$ とわずかに大きかった。さらに, 肩と腰の皮下脂肪厚については差がないことを報告して いる。VAN DER STEEN ${ }^{2)}$ 里子交換により 6 頭と 12 頭に産子を揃え, 子豚の発育と雌豚の発育を調查した。 その結果, 離乳時体重（5 週歯）は 6 頭区と 12 頭区で それぞれ $10.58 \mathrm{~kg}, 8.38 \mathrm{~kg}$ とその差は $2.2 \mathrm{~kg}, 8$ 週 齢体重は $18.74 \mathrm{~kg}$ と $15.77 \mathrm{~kg}$ でその差は $3.0 \mathrm{~kg}$ と いずれも有意な差を見いだした。しかし，100 kg 体重 の背脂肪厚については 12 頭区の $11.15 \mathrm{~mm}$ に対し 6 頭区が $11.05 \mathrm{~mm}$ と $0.5 \mathrm{~mm}$ 有意に厚く、これは代償 
成長によることを報告している。さらに, CHANG $ら^{3)}$ 屯 89 頭の妊娠豚を使い里子交換を含む 8 処理区の実験 で, 豚の出生時から 20 週齢までの発育に及ぼすきょう だい数, 母豚の栄養水準および哺乳時間の影響を調査し た。ここでは, 一腹きょうだい数は 6 頭と 10 頭の 2 区 に設定されている。分析の結果, きょうだい数 6 頭と 10 頭の間には 1 週齢時点の $0.19 \mathrm{~kg}$ （6 頭区 : $2.63 \mathrm{~kg}$, 10 頭区 : $2.44 \mathrm{~kg}$ ) から 10 週齢時点での $1.64 \mathrm{~kg}$ （6 頭 区: $21.13 \mathrm{~kg}, 10$ 頭区: $19.49 \mathrm{~kg}$ ) までその差が増加 し，きょうだい数が大きいと体重が小さくなる。しかし， 12 週齢後, 20 週齢までは統計的に両区で差が認められ なかった。また，松元・新井 ${ }^{7)}$ は系統造成試験のデー夕 について同腹子豚数の差異が発育のどの時期まで影響を 及ぼすかを検討した。その結果，産子数の影響は 5 週齢 までの体重に影響し, 特に選抜された雄と雌について産 子数の影響は 5 週齢から $30 \mathrm{~kg}$ 時までは認められたが, $90 \mathrm{~kg}$ 時までではその影響は認められず, 逆に産子数が 多い方が増体が良くなる傾向が認められたと報告してい る。そして, 種豚候補を選抜する場合には, 5 週齢以後 の区間增体記録を用いれば影響が少ないとしている。本 実験で得られた結果は基本的にこれまで報告された結果 と同様であり, 一腹きょうだい数の違いは豚の初期の発 育には影響するが，その影響は日齢が進むにつれて消失 すると結論される。ところで, 一腹きょうだい数の子豚 の発育への影響は母豚の最大泌乳量に限界があるため, 一腹きょうだい数が増えると子豚一頭当たりの受乳量が 少なくなるため生じると思われるが，むし，母豚の泌乳 能力が増せば一腹きょうだい数の影響は隇少するものと 思われる。一般に, 産次が増すに従い, 母豚の泌乳量は 増加する。STANDAL ${ }^{8)}$ は産次と 3 週齢の産子数が産肉 能力に及ぼす影響を検討した。その結果, 分婏時から検 定時までの 1 日平均増体量について有意な影響を確認し ている。しかし, 産次と産子数との交互作用が認められ, 初産については産子数が多くなるに従い 1 日平均増体量 が小さくなるが, 二産目以降では明らかな差が認められ なくなった。また, 産子数の背脂肪厚に及ぼす影響に関 しては有意な影響が認められなかったとしている。本実 験では初産の子豚の成績だけを用いてきょうだい数の違 いが子豚の発育と育成豚の産肉能力に及ぼす影響を検討 したが, 一腹きょうだい数の子豚の発育や育成豚の産肉 能力に及ぼす影響が二産，三産でも初産と同様か検討す る必要がある。

一腹きょうだい数の繁殖能力に及ぼす影響について, NELSON and ROBISON ${ }^{1)}$ は里子交換により産子を 6 頭
と 14 頭に揃えて, 繁殖能力を調查した。その結果, 各 区で育成された雌豚の分婏時の黄体数と胎児数は 1.01 個 $(\mathrm{P}<0.05)$ と 1.18 頭 $(\mathrm{P}<0.10), 6$ 頭区が 14 頭区 より多いことを報告している。また, VAN DER STEEN ${ }^{2)}$ あ里子交換により 6 頭と 12 頭に産子を揃え繁殖能力を 調査した。その結果, 初回発情日龄の差はなく初産離乳 後の黄体数にも差が認められなかったとしている。さら に, RUTLEDGE ${ }^{4)}$ はヨークシャー豚について分娩後 24 時間以内に産子数を雄 2 , 雌 4 頭の 6 頭に制限する群之 制限しない群で育成された豚について繁殖能力を調査し た。その結果，一腹きょうだい数が小さい（平均 5.77 頭）腹で育成された雌豚の分婏産子数は 11.30 頭で制限 されなかった雌豚（平均 10.06 頭）の 10.19 頭より多か った。また, 雌豚の 21 日齢体重は制限区で非制限区よ り重いが受胎日齢や分婏日齢については差が認められな かったとしている。いずれにしても，比較的わずかな差 であり, 特に系統造成試験などでは育成豚は第 1 次と第 2 次の二回の選拔で発育の優れた個体が選ばれており, 本実験で得られたように一腹きょうだい数の影響は無視 できるむのと思われる。

以上, 今回の分析結果から選抜試験などで敢えて分婏 時一腹の産子数を揃えたり, また検定成績を一腹のきょ うだい数により補正する必要はないことが明らかとなっ た。また, 子豚の時期の一腹きょうだい数が母豚として の繁殖能力に及ぼす影響については, 8 週齢の第 1 次選 抜の時点で発育の遅れた個体が除かれているため今回の 分析結果からだけで結論を下すことは無理がある。一腹 きょうだい数が多く, 発育の劣った雌豚も含む成績にっ いて検討を加える必要があろう。

\section{文献}

1) Nelson, R.E. and O.W. Robison : J. Anim. Sci., 43, 71-77, 1976.

2) Van Der Steen, H.A.M: Livest. Prod. Sci., 13, 147-158, 1985.

3) Chang, H.L., D. Gianola, R.A. Easter, L.H. Thompson : Livest. Prod. Sci., 18, 141-155, 1988.

4) Rutledge, J.J.: J. Anim. Sci., 51, 868870, 1980.

5) Harvey, W.R.: User's Guide for LSMLMW PC-1 VERSION. 1988.

6) 内藤元男, 新編家畜育種学, 養賢堂, $245,1972$.

7）松本 茂・新井忠夫：日豚研誌: 23, 94, 1986.

8) Standal, N. : Acta Agric. Scand., 23, 225231, 1973. 


\title{
EFFECTS OF FRATERNITY SIZE ON THE GROWTH OF PIGLETS, AND MEAT PRODUCTION AND REPRODUCTION TRAITS OF GROWING PIGS
}

\author{
Keiichi Suzuki, Shigeru Nishida, Satoshi UjIIE, \\ Tomoko Fukuda and Hidetoshi Sato \\ Miyagi Prefectural Animal Industry Experiment Station, \\ Iwadeyama-cho, Miyagi-ken, 989-64
}

The possibility of effects of fraternity sizes on the growth of piglets, meat prodiction traits of growing pigs and reproduction traits of sows was investigated. The traits examined were the body weight from birth up to 8 weeks of age, and weight gain of 2216 Landrace line piglets, the meat production traits of 291 growing boars and 735 growing gilts and the reproduction traits of 239 sows of the first down to the sixth generations Landrace line pigs. The piglets were given feed from 2 weeks of age and weaned at 5 weeks of age. The number of the successfully weaned piglets was termed as the fraternity size. The fraternity sizes were classified into 4 groups of less than 7, 8-9, 10-11 and more than 12 .

The differences in the body weight and the weight gain between the group of less than 7 and that of more than 12 piglets were $0.1,0.31,0.58,1.08,1.62,2.04$, and $2.64 \mathrm{~kg}$ at birth, 1, 2, $3,4,5$ and 8 weeks of age, respectively, and $0.47 \mathrm{~kg}$ and $1.47 \mathrm{~kg}$ for the body weight gain from the birth to 2 weeks of age and that from 2 to 5 weeks of age, respectively. All the differences thus noted were significant. It was found out that the larger the litter size, the poorer the growth was. However, the effect of the litter size was not significant upon the weight gain $(0.54 \mathrm{~kg})$ from the 5 weeks down to 8 weeks of age. It was clarified that the effect of the litter size was significant upon the body weights of the growing boars and gilts at age of 8 weeks and upon the age of reaching the body weight of $30 \mathrm{~kg}$, but that the effect of the fraternity size was not appreciable upon the age of reaching the body weight of $90 \mathrm{~kg}$, daily mean weight gain, backfat thickness, daily mean feed intake, feed conversion ratio, selection index value, or numbers of farrowings by sows or number of produced piglets. These results suggest that the effects of fraternity size on the growth, meat production and reproduction traits are tapered off as age advances.

Jpn. J. Swine Science 27, $3: 153-158$

Key words : fraternity size, growth of pigs, meat production traits, reproduction traits. 